\title{
Analysis of colostrum IgA against bacteria involved in neonatal infections
}

\author{
Análise de lgA do colostro contra bactérias envolvidas em infecções neonatais
}

\author{
Elizabeth Moreira Dias ${ }^{1}$, Denise Bertulucci Rocha Rodrigues ${ }^{1}$, \\ Vinícius Rangel Geraldo-Martins ${ }^{1}$, Ruchele Dias Nogueira ${ }^{1}$
}

\begin{abstract}
Objective: To describe e compare the specificity of IgA antibodies against bacteria extract of Klebsiella pneumoniae, Staphylococcus aureus, Escherichia coli, and Salmonella enteritidis. Methods: Colostrum samples were aseptically collected in the first 12 hours after C-section delivery. The specificity of $\lg A$ against bacteria extracts was analyzed by the Western blot. Results: The findings showed proteins of high molecular weight frequently detectable in the samples. $S$. aureus was the most frequently found bacterium in the samples $(p<0.05)$. Approximately $93.8,56.3,62.5$ and $60.4 \%$ of samples presented IgA reactive to $S$. aureus, K. pneumoniae, $S$. enteritidis, and $E$. coli, respectively. Roughly $40 \%$ of samples showed no IgA reactive to $K$. pneumoniae, $S$. enteritidis and $E$. coli. Conclusion: Clinical evidence of the importance of breastfeeding for the immune protection of neonates was consistent with the observed immunological findings, since most samples showed IgA reactive against the species tested. The application and development of immunotherapies during pregnancy, focused on frequently detected antigens, could be an important tool to enhance the presence of $\lg \mathrm{A}$ in colostrum.
\end{abstract}

Keywords: Enterobacteriaceae; Staphylococcus aureus; Colostrum; Immunoglobulin $\mathrm{A}$; Infection

\section{RESUMO}

Objetivo: Descrever e comparar a especificidade de anticorpos IgA de amostras de colostro contra extratos bacterianos de Klebsiella pneumoniae, Staphylococcus aureus, Escherichia coli e Salmonella enteritidis. Métodos: As amostras de colostro foram coletadas assepticamente nas primeiras 12 horas após 0 nascimento por cesariana. A especificidade de IgA contra extratos de bactérias foi analisada por Western blot. Resultados: 0s achados mostraram proteínas de alto peso molecular frequentemente detectáveis nas amostras. $S$. aureus foi a bactéria mais encontrada nas amostras $(p<0,05)$. Cerca de 93,8, 56,3, 62,5 e $60,4 \%$ das amostras apresentaram IgA reativa a $S$. aureus, K. pneumoniae, $S$. enteritidis e $E$. coli, respectivamente. Aproximadamente $40 \%$ das amostras não apresentaram IgA reativa contra K. pneumoniae, S. enteritidis e E. coli. Conclusão: A evidência clínica da importância da amamentação para proteção imunológica ao recém-nascido foi consistente com os achados imunológicos observados, uma vez que a maioria das amostras mostrou IgA reativa contra as espécies testadas. A aplicação e 0 desenvolvimento de imunoterapias durante a gestação, focada nos antígenos frequentemente detectados, poderiam ser importantes instrumentos para aumentar a presença de IgA no colostro.

Descritores: Enterobacteriaceae; Staphylococcus aureus; Colostro; Imunoglobulina A; Infeç̧ão

\section{INTRODUCTION}

Neonatal bacterial infection remains a major cause of morbidity and mortality during the neonatal period. According to the World Health Organization, 6.3 million children under 5 years old died in 2013, and $45 \%$ of them during the neonatal period.(1) In Brazil, about $60 \%$ of infant mortality is mainly due to bacterial infections. ${ }^{(2)}$

The greater susceptibility to neonatal bacterial infection is explained by the relative immunological immaturity of newborns, ${ }^{(3)}$ which is a direct consequence of immune adjustment during the transitional period, from intra- to extra-uterine life. ${ }^{(4)}$ Ontogeny of the

\footnotetext{
Universidade de Uberaba, Uberaba, MG, Brazil.

Corresponding author: Ruchele Dias Nogueira - Avenida Nene Sabino, 1,801 - Universitário - Zip code: 38055-500 - Uberaba, MG, Brazil - Phone: (55 34) 3319-8800

E-mail: ruchele_nogueira@yahoo.com.br

Received on: Dec 6, 2016 - Accepted on: May 4, 2017

Conflict of interest: none.

DOI: 10.1590/\$1679-45082017A03958
} 
immune system begins in the embryo and continues during fetal life, but it is completed only a few years after birth. ${ }^{(5)}$ However, hospital, maternal and obstetric practices may contribute to the occurrence of bacterial contamination that may result in gastrointestinal and respiratory infections, ${ }^{(6)}$ neonatal sepsis and systemic involvement. ${ }^{(2)}$

Neonatal sepsis, the third most common cause of death in early life, results in half a million deaths each year. ${ }^{(7,8)}$ The pathogens most commonly isolated and involved in neonatal infections are Klebsiella pneumoniae, Escherichia coli, Salmonella enteritidis and Staphylococcus aureus. ${ }^{(8)}$

Although E. coli colonizes the gastrointestinal tract of the neonate within a few hours of life and develops a mutualistic relation with the host, ${ }^{(9)}$ this species is the one most frequently involved in neonatal sepsis. ${ }^{(10,11)}$ Some serotypes of E. coli, such as enteropathogenic, enterohaemorrhagic, enteroaggregative and enterotoxigenic, have been reported as the main cause of diarrhea in children under 1 year of age. ${ }^{(12)}$ Also O6 E. coli serotype was detected in many cases of neonatal meningitis ${ }^{(13)}$ and sepsis. ${ }^{(14)}$ Another relevant bacterium associated with neonatal gastrointestinal infections is $S$. enteritidis, which usually appears after the first week of life, and causes acute gastroenteritis and thus serious complications to the newborn, such as sepsis and/or meningitis..$^{(15)}$

Also, $S$. aureus has been linked to various infections during the neonatal period, such as late-onset neonatal sepsis, ${ }^{\left({ }^{8}\right)}$ impetigo, ${ }^{(16)}$ arthritis and osteomyelitis. ${ }^{(17)}$ Virulence antigens of $S$. aureus are predominantly related to bacterial surface, such as capsular polysaccharides, teichoic acid, peptidoglycans, adhesins, protein A, and toxins. ${ }^{(18)}$ Klebsiella pneumoniae is an opportunistic pathogen that causes pneumonia, bacteremia and urinary tract infections ${ }^{(19)}$ and has been reported as a common agent in cases of neonatal sepsis. ${ }^{(20)}$ It is also associated with high mortality, often through strains multiresistant to antibiotics associated to the production of beta-lactamase. ${ }^{(20)}$

After birth, with the interruption of IgG transfer via the umbilical cord, the mother is able to offer to the newborn another form of passive protection, represented by breastfeeding, which has indisputable protective attributes associated to reduction of the risk of neonatal infection ${ }^{(3,21)}$ because it contains several immune components such as secretory IgA (IgAS). ${ }^{(22)}$ The presence of IgAS represents the first line of defense of the mucous membranes, conferring protection against infections and coating mucosal surfaces, preventing the adhesion and invasion of microorganisms in the tissues. ${ }^{(3,21,23)}$

Although exclusive breastfeeding is recommended and practiced, some newborns that are breastfeeding can develop bacterial infection during the neonatal period. There is evidence that children, although being breastfed, can develop diarrhea by Campylobacter due to a lack of specific antibodies against virulence antigens for this bacterium in colostrum. ${ }^{(23)}$ Thus, it is necessary to determine, in samples of colostrum, the presence and specificity of IgA against bacteria commonly involved in neonatal infections, such as $S$. aureus, $K$. pneumoniae, S. enteritidis and E. coli.

\section{OBJECTIVE}

To describe e compare the specificity of IgA antibodies against bacteria extract of Klebsiella pneumoniae, Staphylococcus aureus, Escherichia coli, and Salmonella enteritidis.

\section{METHODS}

A total of 48 mothers were enrolled in this study upon consent. The Ethical Committee approved this study CAAE: 02166713.4.0000.5145. Only healthy mothers, 12 hours after delivery, were included in standard collection. Information on maternal and gestational background was obtained through interviews with the mothers. Samples of colostrum were collected by manual expression into sterile polypropylene Falcon tubes. After collection, the maternal samples were transported in ice to the laboratory, centrifuged at $1,300 \mathrm{~g}$ for 7 minutes to remove lipid components and stored at $-80^{\circ} \mathrm{C}$ until use.

\section{Western blotting of colostrum IgA against bacteria}

Extracts of S. aureus (ATCC 25923), K. pneumoniae (ATCC 13883), S. enteritidis (ATCC 13076) and E. coli (ATCC 11303) were obtained from fresh culture as previously described. ${ }^{(20)}$ Seventeen micrograms of extracts were separated by $6 \%$-SDS-page and transferred to nitrocellulose membranes. The membranes were incubated with colostrum (1:1,000) samples. After washing, they received a solution of antibody HRP- goat anti-human IgA (Sigma) revealed by the ECL system (Amersham Biosciences Little Chalfont, Buckinghamshire, United Kingdom) and exposed in biofilm for five minutes.

The developed X-ray films were scanned in a scanning densitometer (Bio-Rad GS-700 Imaging Densitometer) and the images were evaluated with 
ImageQuant Software (Amersham Biosciences) to analyze patterns of antigen recognition, including the number and intensity of reactive bands. Signals were converted to absolute counts by comparison with the standards on the same membrane. Failure to detect a signal was recorded as zero. A film blank value was subtracted from the value of the reactive band.

Some membranes were incubated with blocking buffer without samples to obtain negative control. As positive control, membranes were incubated with a saliva sample whose pattern of reaction with antigen extracts had been previously measured. The reactive bands represent the presence of IgA specific to proteins separated by the SDS page from each bacterium extract.

\section{Statistical analysis}

The mean number of $\operatorname{IgA}$ bands and densitometry values of reactive Ags were determined and compared between the bacteria by Analysis of Variance (ANOVA). The frequencies of positive IgA reactive to antigens were assessed by $\chi^{2}$ test. The correlations between IgA antibodies and specific to antigens were tested by Pearson analysis. A $\mathrm{p}$ value $<0.05$ was considered statistically significant.

\section{RESULTS}

The mothers were healthy and no complication during or after delivery was reported. Their mean age was $25.2 \pm 3.3$ years. There were no differences in racial profile $(\mathrm{p}>0.05)$. All babies were born full term $(>37$ weeks of gestation). No associations were found between immunoglobulin levels and racial, maternal age, type of birth and socioeconomic data (Pearson, $p>0.05)$. There were also no statistically significant differences between immunoglobulin levels and types of delivery: cesarean or vaginal ( $p>0.05)$.

\section{Specificity of $\lg$ A response against bacterial extracts}

Examples of immunoassays of samples with positive IgA response against the bacterial antigens are represented in figure 1 . The frequencies of samples with positive (with at least one detectable band) and negative responses to the four strains are represented in table 1 . The majority of samples showed reactive IgA against $S$. aureus, followed by $S$. enteritidis, E. coli and $K$. pneumoniae (Table 1). The number of samples with positive response to $S$. aureus was statistically higher than for other bacteria (Table $1 ; \mathrm{p}<0.05 ; \mathrm{q}>15.00$ ).

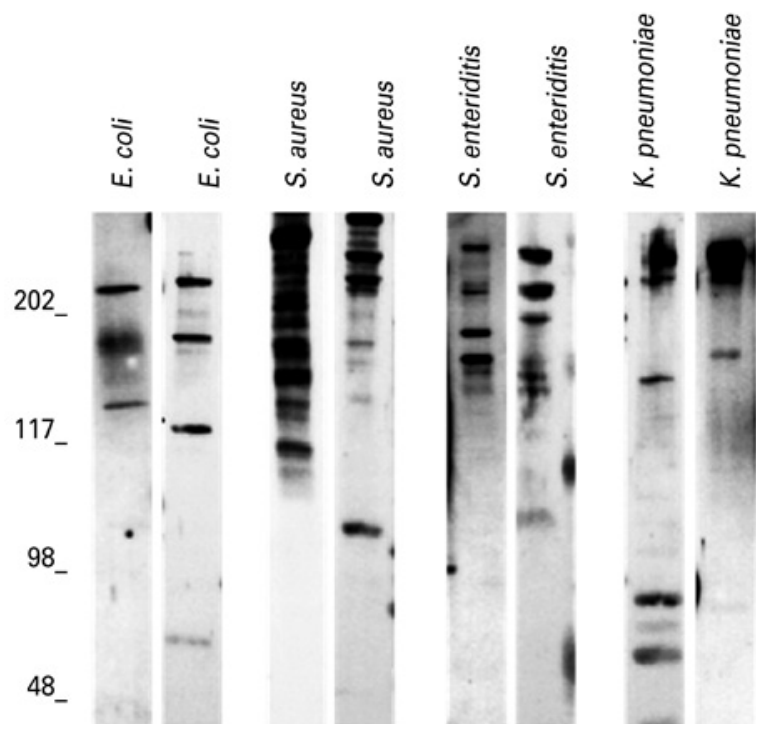

Figure 1. Patterns of IgA reactive against antigens from Staphylococcus aureus, Klebsiella pneumoniae, Salmonella enteritidis and Escherichia coli in samples of colostrum. Identities of antigen extracts are above each lane. Standard molecular sizes $(\mathrm{kDa})$ are indicated to the left of the immunoblots

Table 1. Intensity and frequency of IgA reactive to Staphylococcus aureus, Klebsiella pneumoniae, Salmonella enteritidis and Escherichia coli and antigens detected in colostrum samples

\begin{tabular}{|c|c|c|c|}
\hline \multirow{2}{*}{$\begin{array}{l}\text { Bacterial extracts } \\
\text { and molecular weight } \\
\text { (kDa) }\end{array}$} & \multicolumn{2}{|c|}{$\begin{array}{l}\text { Numbers of samples } \\
\text { with response }\end{array}$} & \multirow{2}{*}{$\begin{array}{l}\text { Mean of total intensity } \\
\text { of colostrum IgA } \\
\text { reactivity } \pm \text { SD }\end{array}$} \\
\hline & $\begin{array}{c}\text { Positive } \\
\text { n (\%) }\end{array}$ & $\begin{array}{c}\text { Negative } \\
\text { n (\%) }\end{array}$ & \\
\hline Staphylococcus aureus & $45(93.8)^{x+f}$ & $3(6.2)^{x+1}$ & $410.7 \pm 186.3^{\text {sf }||}$ \\
\hline 230 & $26(57.8)$ & & $48.5 \pm 41.9$ \\
\hline 221 & $18(40.0)$ & & $33.6 \pm 41.6$ \\
\hline 208 & $25(55.6)$ & & $46.7 \pm 42.2$ \\
\hline 185 & $17(37.8)$ & & $31.7 \pm 41.2$ \\
\hline Salmonella enteritidis & $30(62.5)^{\ddagger}$ & $18(37.5)^{\ddagger}$ & $217.8 \pm 186.3^{35||}$ \\
\hline 244 & $16(53.4)$ & & $31.6 \pm 30.3$ \\
\hline 220 & $16(53.4)$ & & $30.2 \pm 29.7$ \\
\hline 176 & $14(46.7)$ & & $27.0 \pm 29.4$ \\
\hline 144 & $15(50.0)$ & & $28.4 \pm 29.6$ \\
\hline Klebsiella pneumoniae & $27(56.3)^{\dagger}$ & $21(43.7)^{\dagger}$ & $133.2 \pm 101.9^{\text {ff }}$ \\
\hline 244 & $10(37.0)$ & & $16.7 \pm 22.2$ \\
\hline 229 & $7(25.9)$ & & $12.0 \pm 20.7$ \\
\hline 203 & $7(25.9)$ & & $10.9 \pm 19.6$ \\
\hline 194 & $7(25.9)$ & & $12.5 \pm 21.9$ \\
\hline 73 & $8(29.6)$ & & $13.9 \pm 22.4$ \\
\hline 46 & $8(29.6)$ & & $13.3 \pm 20.9$ \\
\hline Escherichia coli & $29(60.4)^{*}$ & $19(39.6)^{*}$ & $251.8 \pm 129.9 \| \#$ \\
\hline 238 & $12(41.4)$ & & $27.7 \pm 33.6$ \\
\hline 216 & $15(51.7)$ & & $34.6 \pm 34.0$ \\
\hline 202 & $15(51.7)$ & & $32.7 \pm 23.8$ \\
\hline 162 & $13(44.8)$ & & $30.0 \pm 33.9$ \\
\hline
\end{tabular}

Complexity of the $\lg A$ response against bacterial antigens The number of IgA bands reactive against $S$. aureus

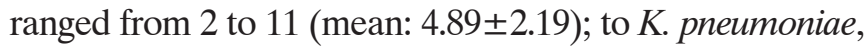


from 1 to 11 (mean: $2.93 \pm 2.19$ ); to $S$. enteritidis, from 1 to 11 (mean: $3.73 \pm 2.21$ ); and against $E$. coli, from 1 to 8 (mean: $3.76 \pm 1.911$ ). Mean number of IgA-reactive bands to microbial antigens from $S$. aureus, E. coli, $K$. pneumoniae and $S$. enteritidis are represented in figure 2. The mean number of bands reactive to $S$. aureus was elevated and there were statistically significant differences in comparison to other bacteria (Figure $2 ; \mathrm{p}<0.05)$. There were no differences in the mean number of bands between $K$. pneumoniae, $S$. enteritidis and E. coli $(\mathrm{p}>0.05)$.

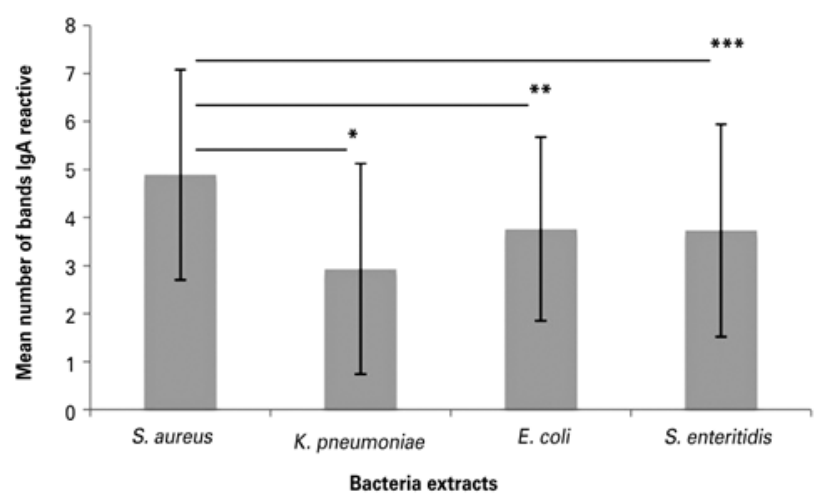

${ }^{*} p=0.02 ;{ }^{* *} p=0.02 ; * * * p=0.04$

Figure 2. Mean numbers of bands of $\lg A$ reactive with the bacterial antigens of Staphylococcus aureus, Escherichia coli, Klebsiella pneumoniae and Salmonella enteritidis in colostrum

\section{IgA specific against the bacterial extracts bands separated by SDS-PAGE}

IgA bands recognized and detected in bacterial extracts were analyzed, and their molecular weight $(\mathrm{kDa})$ was calculated by the equation obtained by the analysis of the molecular weight standard bands. The number of samples with positive IgA to antigens and their respective molecular weight with $S$. aureus, $K$. pneumoniae, $S$. enteritidis and $E$. coli are represented in figure 3. There was a great variation in the bands recognized by $\operatorname{IgA}$ for each bacterial extract, and the majority of them showed a high molecular weight ranging between $247-109 \mathrm{kDa}$. Approximately 59 bands of different molecular weights were detected. A $244 \mathrm{KD}$ a band was common in samples of $S$. aureus, $K$. pneumoniae and $S$. enteritidis but there was no correlation between them $(\mathrm{p}>0.05, \mathrm{r}<0.28)$.

The most detected frequencies of samples with positive response to antigens are represented in table 1. The IgA response against $S$. aureus showed the greatest diversity; more than 20 types of different bands were detected $(\mathrm{p}<0.05)$. The reactivity of IgA against $S$. aureus showed a prevalence of bands with
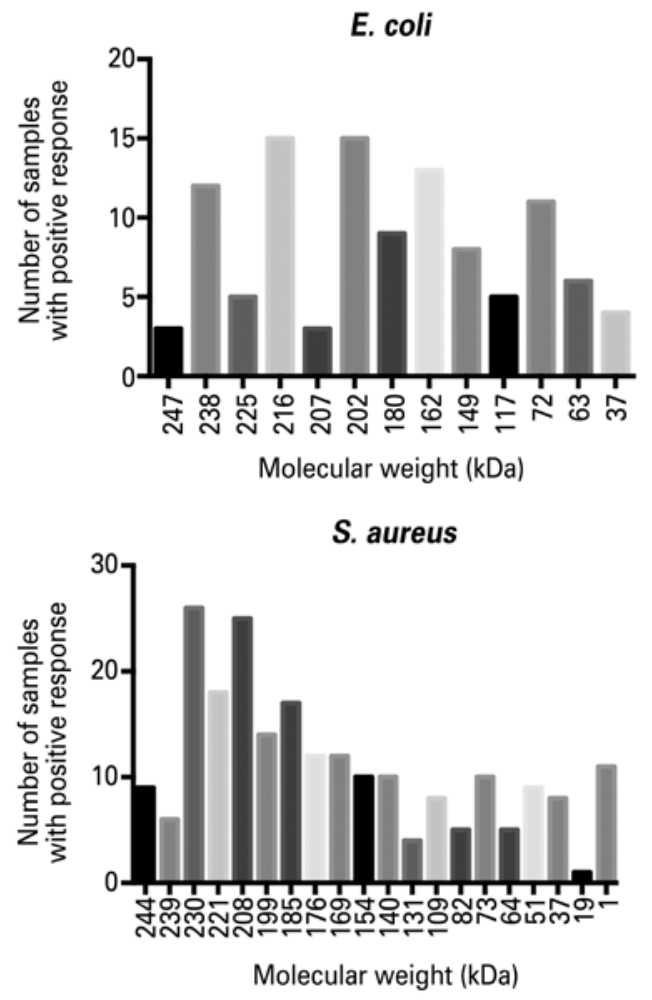

S. enteritidis
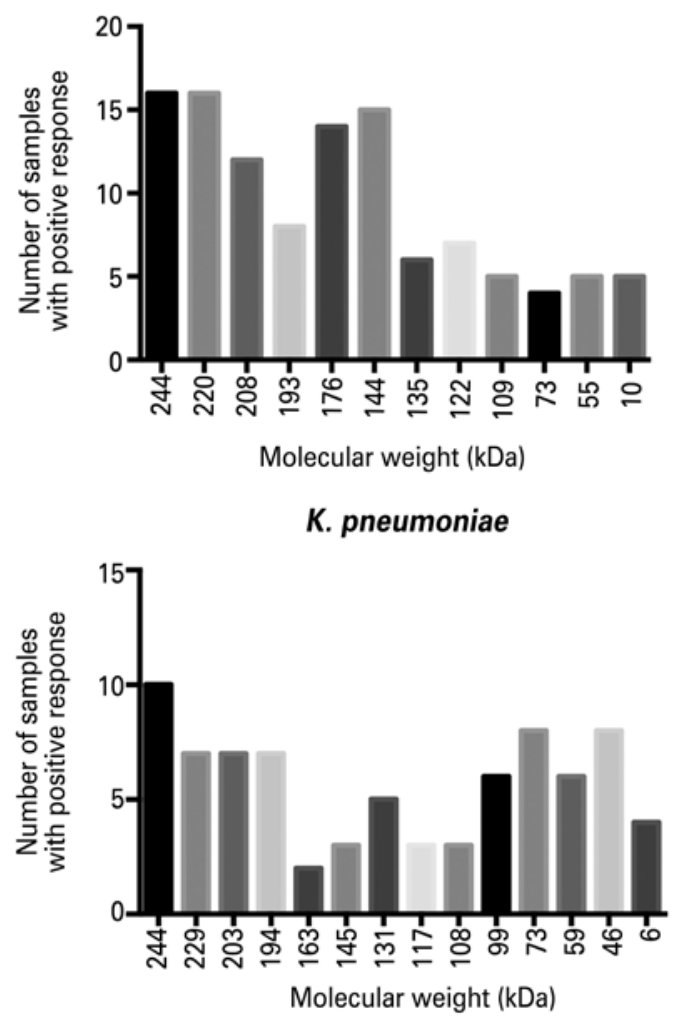

Figure 3. Number of samples with $\lg A$ reactive to specific bacterial antigens and their molecular weights $(\mathrm{kDa})$

high molecular weight $(\mathrm{p}<0.05$, Figure 3$)$. Over $55 \%$ of samples with positive response to $S$. aureus showed IgA reactive to $230 \mathrm{kDa}$ and $208 \mathrm{kDa}$. Twelve different 
bands were found among samples with positive $\operatorname{Ig}$ A to S. enteritidis $(\mathrm{n}=30)$. Bands of 244 and $220 \mathrm{kDa}$ were recognized in $53.4 \%$ of samples and were statistically more detected than the others (Table $1, \mathrm{p}<0.05$ ).

The analysis of IgA against $K$. pneumoniae revealed 14 distinct bands (Figure 3 and Table 1). The frequency of positive response against the most detected bands (Table 1) did not differ $(\mathrm{p}>0.05)$. The immunoblots of IgA against $E$. coli showed 13 different bands (Figure 3 and Table 1), but there were no differences in the frequency of IgA response between these bands $(\mathrm{p}>0.05)$.

There were variations in the intensities of $\operatorname{IgA}$ antibody reactions with the recognized bands among children in both groups. Table 1 shows the sums of intensities of IgA reactions with all bands detected for each species (total intensities). In general, the intensity of IgA response was higher to $S$. aureus than other bacteria $(\mathrm{p}<0.05)$. In addition, the total intensity of $\operatorname{IgA}$ response to $E$. coli was decreased in comparison to K. pneumoniae $(\mathrm{p}<0.05)$.

\section{DISCUSSION}

The majority of colostrum samples had IgA reactive to bacterial antigens, thus corroborating several studies that emphasize the importance of breast milk, which provides protection against infection by Haemophilus influenzae and Escherichia coli, ${ }^{(21)}$ and enteric infections caused by E. coli, Vibrio cholerae, Campylobacter, Shigella spp and Giardia lamblia. ${ }^{(24-26)}$ Thus, breastfeeding can protect neonates against the oral invasion of a large number of microorganisms. ${ }^{(21)}$

The majority of samples (94\%) had antibodies IgA reactive against $S$. aureus accompanied by intense and complex responses, since the number of reactive bands was higher than for other bacteria. This high frequency of reactive IgA probably occurred because this bacterium is part of the normal human microbiota in various regions of the human body, which does not exclude the possibility of this microorganism causing disease under immunosuppression, or when epithelial barriers are violated, which can be limited to the mucosal surface or spread throughout the body. ${ }^{(9)}$

Although the majority of samples had reactive IgA against these bacteria, about $40 \%$ of samples did not present $\operatorname{Ig}$ A reactive to $K$. pneumoniae, $S$. enteritidis or $E$. coli, which suggests that some newborns may develop infections from these microorganisms even though they are breastfed. One of the reasons suggested to explain breastfed children with diarrhea by Campylobacter is a lack of specific antibodies against common antigens of virulence of Campylobacter in samples of colostrum. ${ }^{(23)}$ Thus the importance of not only of studying the presence of $\operatorname{IgA}$ against bacteria, but also of evaluating and identifying immunodominant antigens of these species in the natural immune response.

The reasons for lower or higher detection of antibodies in the samples may be associated to the antigenic stimulation. Thus, it is necessary to implement a strategic stimulation to enhance the immune protection of newborns in their neonatal period against such microorganisms, and increase immunogenic antigens, which occurs in meningococcal infection. Prenatal women immunization, with a single dose of meningococcal vaccine, results in an increase in specific IgG levels in the newborn serum for 2 to 3 months after birth, and an increase of the specific IgA levels to the microorganism in the milk for at least 6 months. ${ }^{(23)}$

The results showed a great diversity of the antigen species tested, with a predominance of high molecular weight protein. The most common bands can be related to the pathogenic action and/or antigenic stimulation of these bacteria, such as 230 and $289 \mathrm{kDa} S$. aureus; and the four most prevalent bands of $S$. enteritidis and $E$. coli are shown in table 1. K. pneumoniae showed a great variability in IgA response, but did not show a specific pattern of response. The literature provides some information about several antigens of these bacteria that are involved in their pathogenic capacities, but little is known about the high molecular weight antigens widely recognized by the samples of this study.

An antigen of $94 \mathrm{kDa}$ called "intimin" and other antigens recognized by IgA of 70,80 and $110 \mathrm{kDa}$ were associated in the injury process "attaching and effacing" by enteropathogenic E. coli in human milk. ${ }^{(6)}$ Also, Rck is a $17 \mathrm{KDa}$ outer membrane protein, expressed in $E$. coli and $S$. enteritidis, which inhibits complementary pathways, thereby preventing opsonization through this route. ${ }^{(27)}$ No sample showed IgA reactive to intimin $(94 \mathrm{kDa})$ and $17 \mathrm{kDa}$ band, but about 38 and $17 \%$ of samples responded to a band of 72 and $117 \mathrm{kDa}$, respectively, probably the same as previously reported.(6) $K$. pneumoniae antigens of 35 and $36 \mathrm{kDa}$ opsonizing induce antibodies ${ }^{(28)}$ and were recognized by $29 \%$ of the present study samples.

The $106 \mathrm{kDa}$ antigen (fibronectin type A) is one of the most important molecules involved in the adhesion in the early stages of infection by $S$. aureus. ${ }^{(29)}$ In addition to those, protein constituents of $S$. aureus membrane of 30 and $36 \mathrm{kDa}$ may play an important role in infections caused by this bacterium. ${ }^{(30)}$ These antigens were detected in $17 \%$ of samples with positive responses. 


\section{CONCLUSION}

The majority of colostrum samples can protect newborns against neonatal bacterial infection. It is important to understand how those antibodies provided by breastfeeding could help the mucosal immune system against the colonization and the challenge offered by those species, in order to develop prevention strategies to avoid such infections. The natural response to bacterial extracts tested shows a promising way for the development of vaccines containing antigens that could be applied during pregnancy, increasing the specific IgA levels in colostrum.

\section{ACKNOWLEDGMENTS}

The Conselho Nacional de Pesquisa (CNPq) supported this study, process number 472928/2007-4.

\section{REFERENCES}

1. World Health Organization (WHO). Global Health Observatory (GHO) data. Underfive mortality [lnternet]. Geneva: WHO; 2017 [cited 2017 Jan 9]. Available from: http://www.who.int/gho/child_health/mortality/mortality_under_five_text/en/

2. Furuichi M, Miyairi I. Risk factors for persistent bacteremia in infants with catheterrelated bloodstream infection due to coagulase-negative Staphylococcus in the neonatal intensive care unit. J Infect Chemother. 2016;22(12):785-9.

3. Petrechen LN, Zago FH, Sesso ML, Bertoldo BB, Silva CB, Azevedo KP, et al. Levels and complexity of $\lg A$ antibody against oral bacteria in samples of human colostrum. Immunobiology. 2015;220(1):142-6.

4. Mussi-Pinhata MM, Nascimento SD. [Neonatal nosocomial infections]. J Pediatr (Rio J). 2001;77(Suppl 1):S81-96. Portuguese.

5. Ndam NT, Denoeud-Ndam L, Doritchamou J, Viwami F, Salanti A, Nielsen $M A$, et al. Protective antibodies against placental malaria and poor outcomes during pregnancy, Benin. Emerg Infect Dis. 2015;21(5):813-23.

6. Gavilanes-Parra S, Mendoza-Hernández G, Chávez-Berrocal ME, Girón JA, Orozco-Hoyuela G, Manjarrez-Hernández A. Identification of secretory immunoglobulin a antibody targets from human milk in cultured cells infected with enteropathogenic escherichia coli (EPEC). Microb Pathog. 2013;64:48-56.

7. Berezin EN, Solórzano F; Latin America Working Group on Bacterial Resistance. Gram-negative infections in pediatric and neonatal intensive care units of Latin America. J Infect Dev Ctries. 2014;8(8):942-53. Review.

8. Downie L, Armiento R, Subhi R, Kelly J, Clifford V, Duke T. Community-acquired neonatal and infant sepsis in developing countries: efficacy of WHO's currently recommended antibiotics--systematic review and meta-analysis. Arch Dis Child. 2013;98(2):146-54. Review.

9. Gomes TA, Elias WP, Scaletsky IC, Guth BE, Rodrigues JF, Piazza RM, et al. Diarrheagenic Escherichia coli. Braz J Microbiol. 2016;47 Suppl 1:3-30. Review.

10. Couto RC, Carvalho EA, Pedrosa TM, Pedroso ER, Neto MC, Biscione FM. A 10-year prospective surveillance of nosocomial infections in neonatal intensive care units. Am J Infect Control. 2007;35(3):183-9.

11. Zaidi-Jacobson M, Ponce de León-Rosales S, Vázquez-Narvaez G, ChableMendoza C. [Prospective study of nosocomial infections at a pediatrics unit]. Bol Med Hosp Infant Mex. 1991;48(8):538-43. Spanish.
12. Dias RC, Dos Santos BC, Dos Santos LF, Vieira MA, Yamatogi RS, Mondelli AL, et al. Diarrheagenic Escherichia coli pathotypes investigation revealed atypical enteropathogenic E. coli as putative emerging diarrheal agents in children living in Botucatu, São Paulo State, Brazil. APMIS. 2016;124(4):299-308.

13. McCracken GH Jr, Sarff LD, Glode MP, Mize SG, Schiffer MS, Robbins JB, et al. Relation between Escherichia coli K1 capsular polysaccharide antigen and clinical outcome in neonatal meningitis. Lancet. 1974;2(7875):246-50.

14. Freij BJ, McCracken GH. Acute Infections. In: Avery GB, Fletcher MA, macdonald MG, editors. Neonatology pathophysiology and management of the newborn. 5th ed. Phyladelphia: Lippincott Company; 1999. p.1082-116.

15. Ferreira E, João A, Ferraz L. Gastroenterite por salmonella em recém-nascido. Rev Nascer Crescer. 2007;16(3):128-9.

16. Jursa-Kulesza J, Kordek A, Kopron K, Wojciuk B, Giedrys-Kalemba S. Molecular studies of an impetigo bullosa epidemic in full-term infants. Neonatology. 2009;96(1):61-8.

17. Montgomery CO, Siegel E, Blasier RD, Suva LJ. Concurrent septic arthritis and osteomyelitis in children. J Pediatr Orthop. 2013;33(4):464-7.

18. Holtfreter S, Kolata J, Bröker BM. Towards the immune proteome of Staphylococcus aureus - The anti-S. aureus antibody response. Int J Med Microbiol. 2010;300(2-3):176-92. Review.

19. Escobar AM, Rocha SS, Sztajnbok S, Eisencraft P, Grisi JF. [Septicaemia caused by Klebsiella pneumoniae - a review of 28 cases]. J Pediatr (Rio J). 1996;72(4):230-4. Portuguese.

20. Vijayakanthi N, Bahl D, Kaur N, Maria A, Dubey NK. Frequency and characteristics of infections caused by extended-spectrum beta-lactamaseproducing organisms in neonates: a prospective cohort study. Biomed Res Int. 2013;2013:756209.

21. Andreas NJ, Kampmann B, Mehring Le-Doare K. Human breast milk: a review on its composition and bioactivity. Early Hum Dev. 2015;91(11):629-35. Review.

22. Castellote C, Casillas R, Ramírez-Santana C, Pérez-Cano FJ, Castell M, Moretones MG, et al. Premature delivery influences the immunological composition of colostrum and transitional and mature human milk. J Nutr. 2011;141(6):1181-7.

23. Hurley WL, Theil PK. Perspectives on immunoglobulins in colostrum and milk. Nutrients. 2011;3(4):442-74. Review.

24. Hayani KC, Guerrero ML, Morrow AL, Gomez HF, Winsor DK, Ruiz-Palacios GM, et al. Concentration of milk secretory immunoglobulin a against shigella virulence plasmid-associated antigens as a predictor of symptom status in shigella-infected breast-fed infants. J Pediatr. 1992;121(6):852-6.

25. Morrow AL, Ruiz-Palacios GM, Jiang X, Newburg DS. Human-milk glycans that inhibit pathogen binding protect breast-feeding infants against infectious diarrhea. J Nutr. 2005;135(5):1304-7.

26. Walterspiel JN, Morrow AL, Guerrero ML, Ruiz-Palacios GM, Pickering LK. Secretory anti-Giardia lamblia antibodies in human milk: protective effect against diarrhea. Pediatrics. 1994;93(1):28-31.

27. Ho DK, Tissari J, Järvinen HM, Blom AM, Meri $S$, Jarva $H$. Functional recruitment of human complement inhibitor C4B-binding protein to outer membrane protein Rck of salmonella. PLoS One. 2011;6(11):e27546.

28. Alcántar-Curiel MD, García-Latorre E, Santos Jl. Klebsiella pneumoniae 35 e $36 \mathrm{KDa}$ porins are common antigen in different serotypes and induce opsonizing antibodies. Ach Med Res. 2000;31(1):28-36.

29. Zuo OF, Cai CZ, Ding HL, Wu Y, Yang LY, Feng Q, et al. Identification of the immunodominant regions of Staphylococcus aureus fibronectin-binding protein A. PLoS One. 2014;9(4):e95338. eCollection 2014.

30. Akashi A, Ono S, Kuwano K, Arai S. Proteins of 30 and 36 kilodaltons, membrane constituents of the Staphylococcus aureus $L$ form, induce production of tumor necrosis factor alpha and activate the human immunodeficiency virus type 1 long terminal repeat. Infect Immun. 1996;64(8):3267-72. 